\section{Johdatus ympäristöaktivistin maailmaan}

Stranius, Leo (2019). Ekoistin muistelmat. Into. 269 sivua.

KIRJAN KANNESSA SEISOO energinen mies, polkupyörä kuin sädekehänä pään yläpuolella. Hän näyttää voittajalta, jolla on tarina kerrottavanaan.

Helsinkiläinen Leo Stranius tunnetaan ekologisen elämäntavan valinneena kuntapoliitikkona ja järjestöjohtajana. Häntä on kutsuttu Suomen diplomaattisimmaksi ekofasistiksi, maltilliseksi idealistiksi ja myönteiseksi vaikuttajaksi. Nuorena Stranius määritteli itse olevansa punavihreä agnostikko, sittemmin kulutuskarkuri ja askeettinen hedonisti, jonka onnelliseen elämään ei kuulu luonnonvarojen yletön kuluttaminen eikä ilmastoanoreksiakaan. Kiinnostuksen kohteita ovat ilmasto, eläinten oikeudet ja kansalaistoiminta.

Ekoistin muistelmat on ympäristöhenkisen pioneerin tarina, joka alkaa 1970-luvulta, jolloin suhtautuminen luontoon liittyviin asioihin oli paljon yliolkaisempaa kuin nykyään. Tarina päätyy nykytilanteeseen, jossa kestävä kehitys, ympäristötietoisuus ja ekologinen elämäntapa ovat keskeisiä koko yhteiskunnallisessa päätöksenteossa.

Stranius omistaa kirjansa lapsilleen ja puolisolleen, "... jotta tietäisitte, mitä tein silloin kun jotain oli vielä tehtävissä, ja muistaisitte, mistä kaikki alkoi." Luvassa on siis henkilöhistoriaa yhteiskuntatasoon liitettynä.
YKSILÖN JA YHTEISÖJEN KUVAILUA JA ANALYYSIÄ

Kirjan rakenne on selkeä ja lukijaystävällinen: alkusanat, neljä jaksoa ja jokaisessa kolme lukua, epilogi ja kiitokset. Sisällysluettelo mahtuu yhdelle sivulle, joten kokonaisuus hahmottuu kertavilkaisulla.

Teksti etenee pääosin kronologisesti. Stranius kuvaa laajasti lapsuuttaan sekä persoonan ja identiteetin kehittymistä 1970-luvun maaseudulla. Yksityiskohtaiset leikit tai kohellukset eivät aina tunnu vievän asiaa eteenpäin, ja lukija alkaa jo epäillä kaiken tarpeellisuutta kokonaisuuden kannalta. Vastauksia saadaan aikanaan: nuoressa herää jotakin teeman kannalta oleellista, esimerkiksi yhteiskunnallinen kipinä. Näin tapahtumaketju muodostuu avainkokemukseksi, vaikkei tätä käsitettä käytetäkään. Suorastaan analyyttista on elämän nivelkohtien ja valintojen seurausten pohdiskelu.

Yhteisötasolla Stranius esittää poliittisen nuorisoliikkeen varhaista vihertymistä ja luontojärjestöjen ympäristöpoliittista terhakoitumista 1980-luvulta lähtien. Hankkeiden ja mielenosoitusten kirjo on avartavaa luettavaa, esimerkkinä performanssit, joissa nuorisojoukko hiihti tai konttasi Helsingin keskustan kaduilla, joulukuussa. Helsingin kunnallispolitiikan

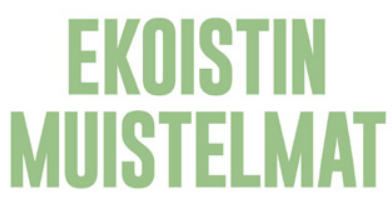

LEO STRANIUS

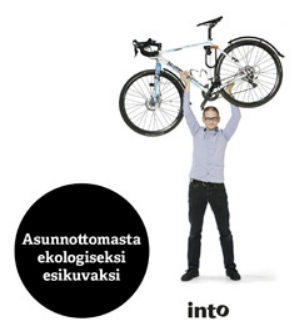

käymistilasta Straniuksella on kokemuksia 2010-luvulta, ja globaalia tasoa edustavat kansainväliset ilmastokokoukset.

\section{ELÄMÄNPOLKU MUTKITTELEE}

Stranius kertoo peruskoulupohjaisesta, mutkikkaasta tiestään yliopistoon ja ympäristöpolitiikan opintoihin. Kirjoittaja raottaa ekoperheen elämänmuotoa, joka vivahtaa suorittamiselta, vaikka ekoisä sen kiistääkin. Ajankäyttö on suunniteltu, aikataulutettu ja määritelty; ekselöimällä mitattu, analysoitu ja dokumentoitu. Kertomus on kuitenkin antoisa, sillä kukin voi poimia esimerkeistä itselleen sopivia ideoita.

Henkilöhistoriallaan Stranius ilmentää vanhoja totuuksia elämänkulkuun vaikuttavista tekijöistä. Hän kuvaa monimuotoisen henkisen ja fyysisen lähipiirin merkitystä erityisesti lapsuudessa. Myöhemmin painottuvat yhteiskunnan tarjoamat mahdollisuudet varsinkin kriisitilanteissa. 
Kaikista näistä mahdollisuuksista sitten tietoisesti valitaan joitain asioita. Monesti sattuma määrää, mihin suuntaa tapahtumat lähtevät kehittymään. Kirjoittajan esittämän tekijäjoukon lisäksi vaikuttaa yksilön kemiallis-fysiologinen ainutkertaisuus, johon taipumukset ja valinnat perustuvat. Herkkyys havaita ympäristöasioita ja kyvykkyys vaikuttaa niihin pohjautuvat siihen geneettiseen koodiin, jonka kukin on elämän ensimmäisissä arpajaisissa saanut.

Koko tarina omasta kehityksestä ja ympäristöliikkeen muotoutumisesta on kolhuineen ja kyynelineen valtaosin kuvailevaa. Toisinaan teksti tuntuu kuin laadulliselta tutkimusmateriaalilta, jota lukijan pitää analysoida saadakseen siitä oleellisen irti. Paikoin kirjoittaja tekee kiinnostavia yhteenvetoja ja hahmottaa kehityslinjoja, jolloin lukija huokaisee kiitollisena.

\section{IDEA, JONKA AIKA ON TULLUT}

Leo Straniuksen ja kumppaneiden toiminta osoittaa yhteistyön voimaa ja vaikuttamisen merkitystä. Ympäristöasioista on tullut valtavirran asioita, eikä toiminta enää ole yksittäisten toimijoiden varassa kuten alkuaikoina. Esimerkiksi vuonna 2019 ilmastonmuutos oli vaalikampanjoissa ja hallitusohjelmassa kärkipaikalla.

Ekoistin muistelmat kertaa tunnettua periaatetta "mikään ei voi estää ideaa, jonka aika on tullut". Ympäristöongelmat kasvoivat 1900-luvun loppua kohti yhä suuremmiksi, niihin herättiin, ja niiden ratkaisemiseksi alettiin toimia.
Tekstiä voikin lukea esimerkkinä innovaation diffuusiosta. Innovaattori ja mielipidejohtaja Stranius oli etujoukoissa tässä toiminnassa, häntä seurasivat ympäristöorganisaatioissa työskentelevät aikaiset omaksujat ja kansalaisten varhainen enemmistö. Nyt mukaan tulee myöhäinen enemmistö, ja vitkastelijat pitävät matalaa profiilia.

\section{YMPÄRISTÖAKTIVISMISTA TUOREESTI JA HENKILÖKOHTAISESTI}

Ekoistin muistelmat liittyy kaltaiseensa kirjallisuuteen. Henkilökohtaisen ympäristösuhteen rakentumista ovat käsitelleet monet tekijät Reino Kalliolasta ja Anto Leikolasta lähtien. Ympäristöliikkeen kehitystä ovat avanneet esimerkiksi vasemmistopoliitikko Paavo Arhinmäki (2006) Punavihreä sukupolvi -kirjassaan, tutkija Helena Telkänranta (2008) toimittamassaan historiikissa Laulujoutsenen perintö ja vihreä poliitikko Satu Hassi (2018) muistelmissaan Mannerheim-solki ja punalippu. Stranius erottuu näistä tuoreudellaan, kuvaus ulottuu vuoteen 2019 saakka.

Miehuusiän välitilinpäätöksellä on oikeutuksensa. Stranius on elänyt ajanjakson, jolloin ympäristöasiat laajenivat henkilökohtaisista valinnoista yhteiskunnallisiksi kysymyksiksi. Kun tekijä tarkastelee menneitä vuosia 2010-luvun lopulla, hän on senhetkinen persoonansa, ja muistikuvat ovat tuon ajankohdan tuottama näkemys asioista. Vuosikymmenen tai parin kuluttua niitä katsoo elämän virrassa eri mies, eikä virtakaan ole enää sama. On taas uusien muistelmien aika.

\section{YMPÄRISTÖTIETOISUUDEN LEVIÄMISEN LÄHIHISTORIA}

Henkilökohtaisen luontosuhteen kehityksen kuvaus ja ympäristötietoisuuden lähimenneisyyden minihistoria ovat hyödyllisiä alan organisaatioissa työskenteleville ja opettajille. Kirjan tematiikka sisältyy perusopetuksen ja lukiokoulutuksen yleisiin tavoitteisiin, joten sen otteita voi käyttää esimerkkeinä yksilön valinnoista, kansalaisvaikuttamisesta ja ympäristöliikkeen kehityksestä. Se sopii aikuiskoulutuksen lukemistoksi käsiteltäessä kestävää kehitystä ja ekologista elämäntapaa. Kun teos on nimensä mukaisesti muistelmat eikä tutkimus, on teoreettinen kehikko hankittava muualta.

Jään uteliaana odottamaan Leo Straniuksen tulevia toimia ja uusia katsauksia. Toteutustapa on makuasia, mutta yksityiskohtien rönsyjen karsinta terävöittäisi sanomaa. Henkilö- ja asiahakemistot laajentaisivat kirjan käyttökelpoisuutta, vielä tukevampi teoretisointi ja kirjallisuusluettelo viitteineen nostaisivat sen uudelle tasolle.

ILTA-KANERVA KANKAANRINTA $\mathrm{FT}$, tietokirjailija 